\title{
PROPAGANDA TECHNIQUES IN FAKE NEWS PUBLISHED BY SERBIAN MAINSTREAM MEDIA
}

\begin{abstract}
Observing propaganda as an essential part of the mass-communication process, its techniques and characteristics are changing constantly, both verbally and visually, adapting to the new trends. As Philip Taylor noted, propaganda is 'a deliberate attempt to persuade people to think and behave in a desired way' which is based on 'the conscious, methodical and planned decisions to employ techniques of persuasion designed to achieve specific goals that are intended to benefit those organizing the process'(Taylor, 2013: 6). If we accept a definition of fake news offered by the Cambridge Dictionary which states that those are 'false stories that appear to be news, spread on the internet or using other media, usually created to influence political views or as a joke', then the relation between the two terms becomes more prominent, especially in the modern age. In that context, the goal of this paper is to examine which propaganda aspects are dominant and in what way they are implemented into contemporary fake news, published in Serbian mainstream media. The theoretical framework will be based on findings of contemporary research in the domain of propaganda communication. Through the qualitative analysis approach the authors will conduct the research focusing on detecting and analyzing propaganda techniques used in confirmed fake news articles in Serbian mainstream media which were discovered and deconstructed by reliable and certified fact checkers (Raskrinkavanje and Fake news tragač). The unit of the analysis will be a deconstructed text which is labeled as fake news. The results of the research are expected to provide an insight into the mechanisms of creating and spreading fake news through popular mainstream media that still play an important role as a public opinion creation agent. Therefore, those results can be used as guidelines for detecting and combating fake news as well as raising awareness about media literacy as one of the most essential competencies today.
\end{abstract}

Key words: fake news, propaganda, fact checkers, mainstream media

\footnotetext{
${ }^{1}$ This paper was presented at the Regional Conference "30 years of higher education in journalism and communication in Eastern Europe after 1989: From conquering the freedom of expression to embracing digital communication", which was held on 21 May 2021 (online conference).

${ }^{2}$ Received July 2021 / Accepted August 2021

${ }^{3}$ e-mail: dusan.aleksic@filfak.ni.ac.rs

${ }^{4}$ e-mail: ivana.stamenkovic@filfak.ni.ac.rs
} 


\section{Introduction}

Although the $20^{\text {th }}$ century is considered a century of propaganda thanks to the scientific achievements in this area, persuasive action as one of the basic propaganda components is as old as the civilization itself. For example, in the $17^{\text {th }}$ century the Catholic Church founded Congregatio de Propaganda Fide for the purpose of spreading ideas and messages among believers, but also for coping with the Protestant movement, by which the propaganda activities were practically institutionalized. This indicates that throughout history propaganda has been a crucial element in important events and communication processes, whose manifestations mostly depended on technological development and the ability to send certain messages to a larger number of people in order to provoke the desired reaction. The development of technology, especially the media, has contributed to the fact that propaganda power and the influence on public opinion only strengthen over time (Soules, 2015). As Jurgen Habermas suggested, the media do not represent the core of a democratic dialogue, but are actually focused on influencing public opinion in order to satisfy elite interests (Habermas, 1991). It can be concluded that propaganda communication is an essential part of public communication, which includes the largest cultural, social and historical context, as well as the dominant communication paradigms at a certain point. One of the definitions of propaganda also refers to a wide range of activities, as proposed by a British author Philip Taylor, which he defines as a "deliberate attempt to persuade people by any available media, to think and then behave in a manner desired by the source" (Taylor, 2013, p.6). Such a broad definition indicates to us that the essence of propaganda action is constant, while only the manner of manifestation changes. For example, in medieval times, the focus was on mass gatherings, placards, pamphlets since those were the available means of communication. Regarding the modern age, we should also take into consideration the change of the communication paradigm, which is based on the change of a one-way communication process to a two-way communication process. In addition, it implies that there is no strict boundary between the communicator and the receiver of the message. For instance, thanks to the virtual space and contemporary media technologies, users also have the opportunity to create content that can influence the opinions and attitudes of a large number of people and contribute to the formation of public opinion. In this regard, the focus of this paper is a media phenomenon that is certainly not new, but which is dominant in the modern media environment. Furthermore, there is the issue of fake news, while the main goal is to examine which propaganda elements are present and how they are used in the creation and distribution of such messages, which directly influences the audience's actions and reactions.

\section{The propaganda function of media coverage}

In their research on the media propaganda and its impact, Noam Chomsky and Edward Herman concluded that the main goal is to "distribute and defend the economic, social and political agenda of the dominant group in the society and 
the state. The media perform this function in several ways: through the selection of topics, spreading concerns, framing problems in a certain context, filtering information, highlighting certain parts and the tone of reporting, directing debate and maintaining the established boundaries" (Herman \& Chomsky, 2010, p.298). The propaganda function of the media in this context shows us that manipulation is never entirely based on lies. Fragments of facts which are upgraded and shaped to provoke a certain reaction are applied. In addition, Marshall Soules calls such propaganda features 'anchors' (Soules, 2015). Also, Darko Tadić writes: "the anchor is, in fact, the starting point for change because it represents something already widely accepted by potential audiences" (Tadić, 2005, p.40). Anchors include beliefs, values, attitudes, behaviors and group norms. Therefore, before every propaganda activity, it is necessary to analyze the target group, its specifics and adjust the action accordingly in order to achieve the desired effect. Also, it should be emphasized that the goal of propaganda is not the dissemination of information, but emotions (Steuter $\&$ Wills, 2009). Propaganda does not rationalize reality and does not provide answers about complex relations and questions. Moreover, it simplifies the image of the world which is created by provoking various emotional reactions (anger, hate, pity, hysteria). Using emotions for the creation, spread and desirable reception of media content has been a part of media production since its occurrence, which indicates a close relation between propaganda communication and media frameworks. Thanks to this principle, numerous media contents are uncritically adopted, which can result in drawing conclusions based on manipulation and deception. In that way, it leads to the activation of propaganda anchors, which in such cases, change in accordance with the preferences of the source of information. Every propaganda action is essentially based on the mythical dimension. Therefore, myths as an important factor of the collective identity make the world more comprehensible and help to create logical models for overcoming contradictions (Lule, 2001; Lévi-Strauss, 1968); they particularly create a factor of recognition and a motive of security in shared experiences (Mead, 1934). The most common way of exploiting myths is the use of stereotypes. Although there are various definitions of stereotypes, in this context we can define them as a kind of simplification by which all members of a certain group are defined with the help of a simply recognizable set of characteristics. In other words, we use stereotypes to draw conclusions and judge people and events on the basis of indirect information, in which the media play a crucial role and not on the basis of personal experience. Also, they are deeply rooted in social consciousness and determine the way we see other cultures in relation to ourselves (Tanikawa, 2019; Stangor, 2016). According to Mirjana Vasović, the use of stereotypes in propaganda communication causes people to search for "the qualities they expect to find when they meet a representative of a given category; therefore, it is an effective method of inducing certain attitudes and controlling behavior" (Vasović, 2004, p. 262), which makes them an ideal means of achieving a propaganda goal. Since myths, as a framework of stereotypes, have an important role in determining the characteristics of collective consciousness, as well as social, cultural and moral frameworks, they are sometimes difficult to detect in media texts. However, for a successful propaganda 
action, the propagandist must know the audience and the specifics of each group in order to be able to predict the answer. Therefore, each propaganda message should be adjusted to the specifics of the intended group otherwise the desired effect will not be achieved. For example, the framework of a propaganda activity based on the mythical dimension of collective consciousness of Serbian citizens will be ineffective in the societies of another cultural model. This feature is one of the key connecting elements between propaganda communication and fake news, which will be discussed in more detail later in the paper.

\subsection{Dominant propaganda techniques}

The Institute for Propaganda Analysis, founded in 1937 in the United States, greatly contributed to the study of propaganda. It was also the first organized and systematic attempt for researchers from the field of social sciences to analyze the significance, techniques and effects of propaganda (Tadić, 2005, p. 87). Although modified, the obtained results are still being used today as the basis in the research of propaganda communication, especially in the domain of defining dominant propaganda techniques (Soules, 2015). In national literature, these techniques are defined as the "seven horsemen of the apocalypse" (Tadić, 2005, p. 141-143) and they include:

1. Name calling - Assigning a set of negative characteristics to a person or a group marked as an enemy. It can be the basis for demonization and dehumanization;

2. Glittering generalities - The opposite of name calling. It is used when it is necessary to form a highly positive opinion about a person or group;

3. Transfer - Assigning symbols or a set of characteristics to persons or groups who do not necessarily possess them in order to use them for creating the desired image in the public (often used during public speaking of politicians and other public figures from other fields);

4. Testimonials - Making true or false statements about which the conclusion is not reached based on the arguments, but based on the credibility sources and a person who makes those statements (for example, when successful actors and athletes promote a certain product, statements of experts, etc.);

5. Plain folks - Refers to situations when people who are the subject of propaganda are placed in a context to which they do not belong. It is often used in political campaigns when candidates visit rural areas, meet and spend time with ordinary people, do their jobs, etc.);

6. Card stacking - A propaganda technique that belongs to the domain of logical manipulation. For the purposes of this technique, information or fragments of information which are true are selected after which a message with a propaganda purpose is constructed (Christians believe in God Muslims believe in God-Christians are Muslims). This is one of the most convenient techniques for creating fake news;

7. Bandwagon - A propaganda technique based on the fact that our actions are conditioned by the accepted patterns of the group we belong to, 
specifically, we do something just because others do it, but without critical analysis.

These propaganda techniques are often combined with a category called "special propaganda techniques" which includes: appeal to fear (induction of fear as a strong emotional reaction that controls group actions), appeal to emotion (creation and distribution of messages that provoke emotional reactions instead of rational), repetition, red herring (diverting attention, spin) and factoids (spreading rumors with the aim of discrediting a certain person or group) (Tadić, 2005, p.153-167). According to Soules, propaganda messages often contain a combination of several propaganda techniques so their framework in the modern context of misinformation and alluring images and videos are often manipulative - the same features that characterize fake news (Soules, 2015, p. 37-64).

\section{Fake news - searching for truth in a digital labyrinth of information}

With the opening of new communication spaces, a modern man is faced with an abundance of diverse information, which they can neither adequately process nor analytically reexamine. The absence of a critical distance towards media contents and information disseminated on social media is associated with the loss of an active attitude towards the interpretation of social reality. Information "disorder" in media recipients, indicated by a large amount of information rapidly spreading and multiplying, causes a state of anxiety, fatigue and a disturbing feeling that all content cannot be followed; therefore, a complete observation of events in a dynamic social environment seems unattainable. A great deal of information comes from unreliable sources, media users or entities who want to deceive or mask a particular problem by focusing the attention of the public on other topics, or want to create and impose a positive or negative impression on an individual or group.

For theorists and researchers of various social disciplines, in the last few years, the phenomenon of fake news has been in the center of interest.

Although this notion and phenomenon has become popular in public discourse, there are difficulties in properly defining $\mathrm{it}^{5}$. There are many definitions of the term fake news, but an essential feature refers to the presence of deceptive content and their various goals and effects. While there is an interpretation among Serbian authors that fake news actually represents misinformation (Surčulija Milojević and Kulić, 2010), foreign authors associate it with various phenomena such as satire, parody, fabricated news, photo manipulation, advertisements, promotional content and propaganda (Tandoc, Wei Lim \& Ling, 2018, p.141-146). In the media and political practice, in addition to misinformation, different forms of manipulation belong to the category

\footnotetext{
${ }^{5}$ The phrase fake news became extremely popular in public discourse after the 2016 presidential elections in the United States (Vamanu, 2019). The analysis conducted by the New York Times database showed that this phrase appeared 319 times in the period from July 1 to December 31, 2016 (Barclay, 2018).
} 
of fake news, as well as bad journalism with errors in reporting. Also, fake news can be defined as an unacceptable opinion (Kulić, 2019), specifically the opinion of a person or group we want to discredit. It is about the misuse of the term "for what is false, fake, another thing was presented; the unacceptable, non-dominant opinion was presented to one side, as opposed to the ingrained and dominant image of the world, in other words, a certain, dominant policy (Kulić, 2019, p.6). Hunt Allcott and Matthew Gentzcow interpret fake news as "journalistic texts that are deliberately and factually false and can deceive readers (Allcott \& Gentzcow, 2017, p. 213). After analyzing the examples from journalistic practice, Milica Kulić reached a conclusion that a distinction should be made between the terms close to fake news and suggests a division that separates a satire/parody and wrong news/fake news. While in satire and wrong news there is no intention of deceiving the recipients of the message, the main component of fake news is a conscious and intentional deception, fabricated with a specific goal (Kulić, 2019, p.13). Similarly, other authors make a distinction between certain types of fake news, while emphasizing paid fake news (profitoriented, regardless of the content), fake news with an agenda (propaganda) and satirical fake news (humorous or in the form of political or social criticism) (Barclay, 2018, p. 55-56).

Significant social and political events are the trigger for the intensive production of fake news. In accordance with that, every election process or a crisis in the society is followed by an overproduction of fake news. The growing number of such information diverts the audience's attention from one aspect of reality to another, deceives it and assures it is the truth and the only possible interpretation of the social world. This reveals the fact that fake news participates in the construction of social reality and the interpretation of social phenomena. Considering that they influence the informing of citizens and the decision-making process and undermine the democratic system, fake news is an issue which the media, the audience and actors who organize and implement the election process encounter (Surčulija Milojević \& Kulić, 2020).

In addition, the circumstances of communication are different and the production and transmission of fake news in the digital environment require an urgent solution. Changed communication ecology, digitalized media and new communication platforms have transformed the way of creating and spreading fake news by giving the impression of a new phenomenon (Surčulija Milojević \& Kulić, 2020). Taking into account the change in the model of communication from the vertical, one-way to the two-way, horizontal type, fake news is easier to transmit and multiply and it is harder to reveal their deceptive character.

The properties of communication, limited by the users' anonymity, the profile of interest and the worldview contribute to this. In technologically advanced media ecology, the role of algorithms is also important since they govern the audience's information about topics they are interested in. By leaving "digital fingerprints", users of digitized media leave traces used by search engines or interested subjects primarily for advertising purposes. "Closing" users in the so-called echo chambers which are shared with the like-minded people, or overflowing them with 
information in accordance with the previous user activities (filter bubbles), the possibilities for spreading and accepting fake news are increased. The term echo chamber is a metaphorical way of describing a situation in which only certain ideas, information and beliefs are shared (Sunstein, 2001; Jamieson \& Cappella, 2008), so the communicators in these filtered balloons only enhance their existing beliefs, without those who do not share the same opinion and question attitudes. Selective exposure can be viewed as the primary cause of creating filtered balloons on social media, which is intensified in the secondary way, particularly by the influence of algorithms, so these mechanisms result in network personalization. The algorithm gives priority to the type of content with which users interact to a large degree, either by commenting, expressing emotional reactions in posts or sharing with other users. This coordination of content with interests and desires of an individual is a consequence of the constant need of a network capital holder to keep the users "involved".

Eli Pariser calls the filtering mechanisms that enable this "prediction engines"; they create a unique universe of information for every user and fundamentally change the way users obtain information (Pariser, 2011). Social media significantly contributes to the information abundance by accelerating the transmission of news and different information, including the false ones, to the unperceivable limits. By placing an individual into a "capsule" of information coordinated with existing mental models, with previous knowledge and memory, social media creates a distorted notion that the image of the world the users receive is credible, complete and reliable. Outside this informative zone different information remains, which could cause a reconsideration of the existing knowledge and beliefs. Users of these information services are, therefore, already misled because they are not familiar with the mechanism of filter operation through which information passes, believing that information they receive represents a "wider universe of data existing online" (Cook, 2018, p.27). Echo chambers and echo balloons can increase the probability that an individual transmits fake news in several ways. Among the connected people there are always those who tend to believe the news, which affects social credibility and strengthens beliefs. Secondly, individuals are more likely to be exposed to fake news and the exposure intensifies the existing belief, while information that is not in accordance with the ideologically consistent, but false news will be less frequent. Finally, there is the possibility of normative pressure to spread fake news (Ackland \& Gwynn, 2021, p.30). This is evidenced by the data on fake news that were used in the presidential elections in the United States in 2016. Fake news in favor of Donald Trump was shared on Facebook over 30 million times, while in the case of Hillary Clinton such news was shared 7.6 million times on the same social media (Allcott \& Gentzcow, 2017).

\subsection{The "encounter" of propaganda and fake news}

There are numerous difficulties in establishing the limits of certain, very close concepts such as fake news and propaganda. While some authors equate fake news 
with propaganda (Tandoc et al., 2018), others believe there is a relationship between them that does not have to be identifiable. Milica Kulić believes that political propaganda can use fake news, however it should not be claimed that everything in propaganda is based on fake news. In addition, they can indirectly influence political decisions and voter behavior, although fake news can also have non-political content (Kulić, 2019, p.12). However, some political figures often label the content they want to discredit as fake news, using this phrase as a manner of political conflict. In spite of being placed in the political sphere, fake news, as a form of fabricated, invented information is predominantly present in the domains of consumption, health and finance (Greifeneder, Jaffé, Newman \& Schwarz, 2021, p.2). Furthermore, there are opinions that propaganda can be interpreted as a subset of fake news. Propaganda is intentionally created in order to advance a political, organizational or commercial agenda, which cannot be said for all fake news (Barclay, 2018, p. 30).

In accordance with the notion that fake news can occur in any area of society, there are two dominant motives for imposing fake news; the first is of economic nature, the second is ideological. In the first case, the creators of fake news can earn a lot of money from advertising if the news goes viral on social media, because every click on the original page brings profit. The second motive is ideological and serves to improve the position of political candidates (Allcott \& Gentzcow, 2017, p. 217). Although neither propaganda nor fake news is a new phenomenon, there are new things about them caused by digital technology, such as: the abundance of information and the difficulty of adequately evaluating them, the facilitated way of distributing fake news to a large audience at low prices and the facilitated way of the change of data (photograph, audio and video materials) with the aim of deceiving message recipients. In addition, misinformation spreads rapidly as a result of the sophisticated tools for deceiving the audience. A particularly prominent place among them belongs to political bots, to programs which generate political messages with the help of algorithms. Instead of people, the software is progressively creating articles that mislead the audience. Also, the optimization of search engines can also deceive the audience by ranking a searched item of information, so that less credible information is at the top of the search results, while the more credible one is at the bottom (Barclay, 2018, p. 48-56).

Although there is a difference between fake news and propaganda, their domains overlap, so fake news can be used for propaganda purposes, but can also be part of the agenda of authoritarian political leaders (McIntyre, 2018). Relying on the argumentative theory and a critical analysis of discourse, Iulian Vamanu (2019) emphasized ten ways in which fake news can be used for propaganda purposes, such as: the dialogue structure (the key issue is the credibility of the source of the message), message content (what is claimed and with what evidence), the goal-oriented structure of the message (whether it is about "supporting" or "undermining" propaganda), the involvement of social groups (fake news oriented towards a specific social or political group, where the opposing group is attacked), the indifference to logical reasoning (using logical reasoning only if it is in line with propaganda's goals), one-sided argumentation (alternative viewpoints are not used in propaganda), the involvement of persuasion dialogue (there are several important elements: the central topic and stating the cause of a problem; consequences are considered in relation 
to certain values and principles (reference values); certain individuals or groups are held responsible for their acts (responsibility), ways of solving problems are presented (need for action) and the authors of false news can position themselves and others (the other side) in ways that support their statement; justification by results (action will lead to expected results), emotive language and persuasive definitions (fear is the most present emotion in fake news) and eristic aspect (reliance on the dichotomy in defining specific groups) (Vamanu, 2019, p.201-207). Keeping in mind that the term "fake news" is used by different individuals and groups and that it may contain the elements of truth, although deprived of context and politically manipulated, Siva Vaidhyanathan warns that the main problem must not be neglected. It is not solved by noticing and refuting such problematic contents, but refers to the endangerment of civic norms and institutions. "Misinformation divides and weakens the state. When the exposure to them lasts, the notion of trust becomes comical, the notion of truth irrelevant and the notion of justice is compared to a tribal revenge or retaliation" (Vaidhyanathan, 2018, p.189).

Taking into consideration the omnipresence of fake news, various solutions to the problem of misinformation are suggested, which can be classified into four categories: algorithmic, corrective, legislative and psychological (Van der Linden \& Roozenbeek, 2021, p.150). While the first three ways of combating fake news are not effective enough in practice, the psychological perspective which empowers individuals to deal appropriately with misinformation represents a promising opportunity. This primarily refers to the role of education, media literacy and critical interpretation of harmful media content. The disadvantages of the traditional approach to media literacy are reflected in the fact that not all content with fake news can be corrected. Also, despite the developed techniques of better detection of such content, the invasion of fake news cannot be prevented. Moreover, adopted misconceptions obstruct the subsequent change of attitudes. One of the psychological models of exposing fake news is found in the inoculation theory which is based on the analogy with immunology. The mechanism of a vaccine and information's effect is the same: if a weaker version of misleading information is presented to somebody, the person develops "mental antibodies" which makes that person resistant to unwanted persuasive influences. The inoculation theory offers a framework for the "development of a broad-spectrum immunization against fake news" (Van der Linden \& Roozenbeek, 2021, p. 163). Donald Barclay introduced a list of nine questions that should be asked in the evaluation of information sources. These are the following questions:

1. Who is the creator of the information?

2. Who released the information?

3. How is the content related to the headline?

4. Which sources are cited?

5. When was the information created?

6. What do others have to say about the information?

7. Does the information come from a primary source or a secondary source?

8. Is the information satirical?

9. Is the information different from everything you have seen so far? (Barclay, 2018, p. 101-110). 
In media education, many authors recognize the key to solving problems caused by fake news. However, according to Danah Boyd, the concept of media education should be adjusted to the current communication environment whose foundations were developed on the networked type of communication (Danah Boyd, 2018). While the first wave of media literacy was a response to propaganda in the context of the mass media, in the second wave of devising an acceptable and effective strategy, the intertwining of networks and the understanding of information which is produced and transmitted in a different way than before should be taken into account, as Boyd suggests. Feedback in the process of media literacy of the audience can indicate criticism and distrust towards the traditional media. This would lead to new paths of misinformation and deception of different kinds on the web. In that way, a vicious circle of harmful content is created, from which it is hard to escape.

\section{Methodological framework}

For the purpose of the analysis, a quantitative-qualitative content analysis was applied, while the unit of analysis was the text. The corpus included 42 texts published in Serbian mainstream media from January 1 to April 30, 2021 for which the verified fast checkers Raskrinkavanje and Fake News Tragač found out that they were fake news, by using the process of deconstructing the published material. Quantitative analysis was used to classify propaganda techniques from the theoretical part of the paper and to determine their number in each of the analyzed texts. In addition, the qualitative analysis examined the way in which the dominant propaganda techniques were applied.

\subsection{Quantitative analysis}

As pointed out in the methodological part, a total of 42 texts published in Serbian mainstream media were analyzed, which were confirmed to be fake news. The propaganda techniques that appear in them are classified as follows. It is important to note that a text may contain several propaganda techniques.

Table 1 General propaganda techniques

\begin{tabular}{|l|c|}
\hline Misinformation & 42 \\
\hline Photo manipulation (a photograph or video) & 14 \\
\hline Mythological dimension & 4 \\
\hline Stereotypes & 3 \\
\hline
\end{tabular}

Predictably, each of the analyzed texts contained misinformation, which essentially makes the core of fake news. Photo or video manipulation was used in 14 cases, which makes up a third of the analyzed corpus, while the texts with a principal stronghold in the mythological dimension as an important element of collective identity were noticed in four cases. Stereotypes were expressed in only three cases. 
Table 2 "7 war tactics"

\begin{tabular}{|l|c|}
\hline Name calling & 10 \\
\hline Glittering generalities & 1 \\
\hline Transfer & 2 \\
\hline Testimonials & 4 \\
\hline Plain folks & 0 \\
\hline Card stacking & 11 \\
\hline Bandwagon & 11 \\
\hline
\end{tabular}

Regarding the dominant propaganda techniques, also known as the seven war tactics, Card stacking, Bandwagon and Name calling were mostly represented. As mentioned previously, Card stacking is a convenient technique for creating fake news because it is based on the manipulation of facts. In addition, the fragments of true statements are being used, which are later combined and/or upgraded into a desired propaganda message. In this case, Bandwagon greatly refers to the publication of certain information without the previous evidence of accuracy, specifically the texts that are published just because others have also published them. Name calling is one of the oldest and the most used techniques in propaganda communication in general, which, according to the results of the research, appears in fake news in a significant percentage.

Table 3 Special propaganda techniques

\begin{tabular}{|l|c|}
\hline Appeal to fear & 10 \\
\hline Appeal to emotion & 1 \\
\hline Repetition & 8 \\
\hline Red herring & 1 \\
\hline Factoids & 2 \\
\hline
\end{tabular}

Among the special propaganda techniques, as expected, the most common was the appeal to fear. Spreading fear and panic is one the main characteristics of fake news. Taking into consideration that the research was conducted during the coronavirus pandemic, such circumstances contributed to the spread of fake news with such features. All texts in which the motive of repetition was noticed can also be connected with the pandemic. Although only one text containing the dominant technique of the appeal to emotion was detected, it should be emphasized that propaganda communication itself is based on the spread of emotion. Therefore, it can be concluded that the motive of emotional manipulation is actually present in all analyzed texts.

\subsection{Qualitative analysis}

In this part of the analysis, several examples of the practical implementation of the propaganda techniques described in the previous chapters will be presented. 


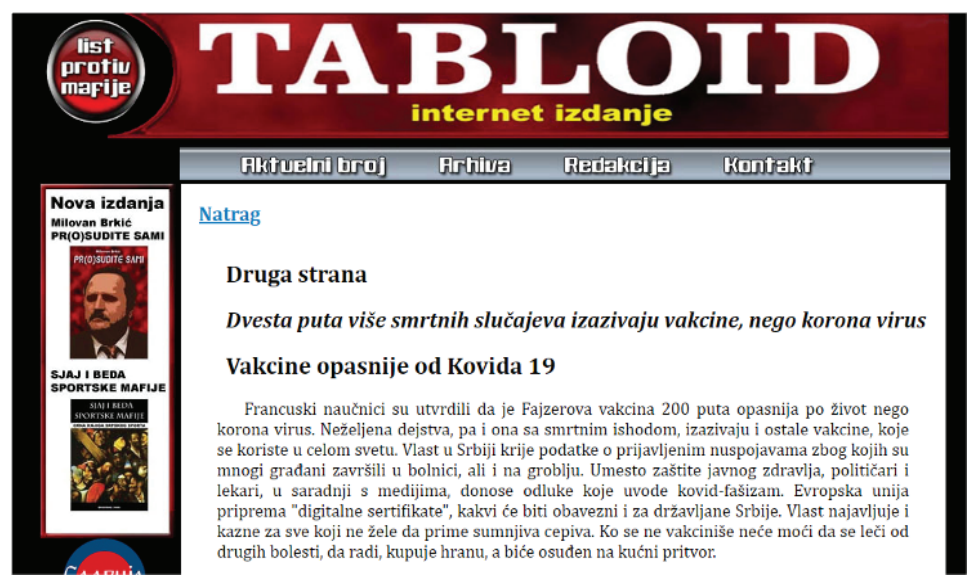

Photo 1 The text published in the weekly magazine Tabloid about the vaccines' harmful effects

In the text published in the online and print version of the weekly magazine Tabloid, it is stated that French scientists have confirmed that the vaccine against the coronavirus is 200 times more harmful than the virus itself. Precisely those texts or the ones with a similar content were used for spreading fear and panic during the pandemic, which is another example of the propaganda technique called the appeal to fear, as well as repetition. The intensity of emotional manipulation and its induction, which is expected to cause a strong negative reaction of the public, is intensified by the technique name calling. In this case, all measures aimed at suppressing the virus are called Covid-fascism.

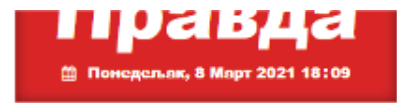

\section{ЈАПАНСКИ НОБЕЛОВАЦ: Корона је вештачки створена, убили су лаборанте у Вухану?!} Јапански професор физиологије и медицине и добетник Нобелове награде

Photo 2 The false statement of a Japanese Nobel laureate 
This text is an example of the propaganda technique testimonials, because the Japanese Nobel Prize winner is used as the source of credibility, despite the fact that it was proven he had never declared that the Covid-19 was an artificial creation and that laboratory workers in Wuhan were murdered.

However, some readers do not check these statements, since content constructed in such a way may appear convincing, which may lead to its massive dissemination. Given that the text is also about the pandemic, it can be an example of the combination of the testimonials technique with the appeal to fear and repetition techniques.

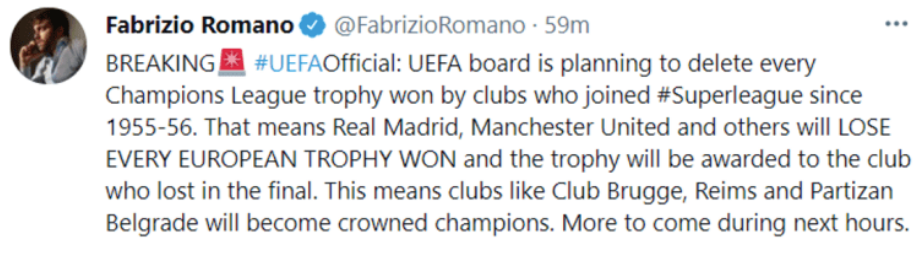

Q 271 七 $1.4 \mathrm{~K} \quad$ ○ $10.6 \mathrm{~K} \quad$ 个

Photo 3 The fake tweet about trophies taken away

The fake tweet posted by a sports journalist, Fabrizio Romano, about UEFA's plan to take away the trophies of the teams which won the European Cup/ the UEFA Champions League, if they happen to play in the new Super League, went viral in the Serbian media. The main reason is that the trophy would then be awarded to the national club Partizan. Although a maximum of 280 characters is available on Twitter, 420 characters here indicated that it was a photomontage. However, it did not stop the national media from massively spreading this information as credible. In addition to the apparent photo manipulation, the bandwagon technique was also present here.

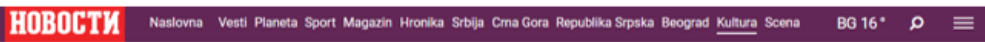

CT Forma lobur Lat MuP

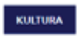

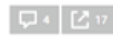

\section{OGROMAN USPEH "DARE IZ JASENOVCA": Srpski film prošlog vikenda najgledaniji u američkim bioskopima}
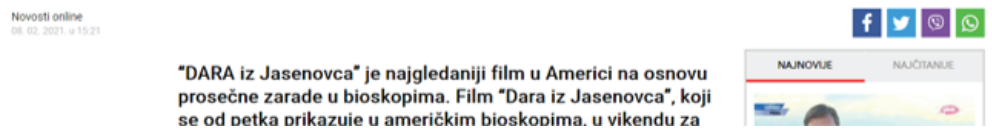

Photo 4 Fake news about "Dara of Jasenovac" being the most watched film in the United States 
The text published by numerous portals which stated that the Serbian film "Dara of Jasenovac" was the most watched film in American cinemas is a typical example of the propaganda technique known as card stacking. Namely, the text stated that the film achieved the highest average revenue in cinemas across America, which is accurate information. However, out of several thousand cinemas that exist in the United States, the fact that the film was shown in only 12 selected cinemas was disregarded. Considering that this is a film of great emotional value for its people, the publishing and the effect of this information have a mythological dimension. The film's central theme is the suffering of the Serbian people that took place at the Jasenovac concentration camp. In addition, the film caused the reinterpretation of those events in collective consciousness, so such misinformation contributes to the strengthening of national pride and achieving historical justice, which is a feature of the propaganda technique called the appeal to emotion.

\section{Conclusion}

Even though in the modern age fake news is associated with misinformation spreading through various online platforms (for example, social media), the analysis revealed their presence in the discourse of the mainstream media. Given that important events and significant social changes, such as the coronavirus pandemic, are triggers for the mass production of fake news, it can be concluded that we are living in the era of infodemic which implies a huge influx of information from several sources, many of which are not true. On the issue of the mainstream media, as a platform for distributing fake news, we can identify the double principle of their distribution. Fake news published in this way may be a result of an abuse of a media platform for the deliberate spreading of misinformation. This is not necessarily related to the spread of fear and panic in order to achieve economic and political interests, actually the medium is used for expressing one's personal beliefs and attitudes in the form of credible information according to the echo chambers principle. On the other hand, with speed having a primary role in modern journalism, as well as the need to publish essential information as soon as possible without previously checking it only indicates a lack of professionalism to verify information. With this model being a typical example of the bandwagon technique, the audience also remains deprived of another important feature in journalism - accuracy. The analysis of the very texts that were found to be fake news has indicated that the principle of creating such content does not differ much from other forms of propaganda communication. In this case, in order to achieve the desired effect, it was necessary to apply the appropriate propaganda techniques. As pointed out by the findings of the quantitative analysis in the analyzed corpus, the techniques appeal to fear and name calling were dominant - the same techniques predominantly used and which manipulatively provoke strong emotional reactions. For the very structure and form of the message, the card stacking technique was used for the purpose of logical manipulation. Also, the use of visual manipulation was detected. 
The transformation of the communication model from the vertical to the horizontal one has enabled everyone to become a content creator, which increases the amount of false information that can be found in the public discourse. However, as the research has shown, even the professional media which possess the higher degree of credibility are not impervious to the creation and distribution of such content, which can lead to general confusion and deception of the public. In addition, this is particularly dangerous in times of crisis. Moreover, the results unequivocally showed there is a lack of competences in the field of media literacy, not only among the audience which accepts this information, but also among those who are considered to be professional media workers. Therefore, in order to suppress infodemic and information chaos, the activities of both content creators and users must be focused on the acquisition of these skills and competences.

\section{References}

Ackland, R., Gwynn, K. (2021). „Truth and dynamics of news diffusion on Twitter“. Eds. R. Greinfeneder, M. E. Jaffé, E. J. Newman \& N. Schwartz. The Psychology of Fake News: Accepting, Sharing, and Correcting Misinformation. (pp. 27-46). London and New York: Routledge.

Allcott, H., Matthew G. (2017). „Social Media and Fake News in the 2016 Election“. Journal of Economic Perspectives 31 (2), pp. 211-236. DOI: 10.1257/jep.31.2.211

Barclay, A. D. (2018). Fake news, propaganda and plain old lies. Lanham, Boulder, New York, London: Rowman \& Littlefield.

boyd, d. (2018, March 9). „,You think you want media literacy... Do you?““ [Blog post]. https:// points.datasociety.net/you-think-you-want-media-literacy-do-you-7cad6af18ec2 (posećeno 15. 4. 2021.)

Bruns, A. (2019). Are Filter Bubbles Real? Cambridge: Polity Press.

Cook, A. N. (2018). Fake news and alternative facts. Chicago: ALA Editions.

Greifeneder, R., Jaffé, E. M., Newman, J. E., Schwarz, N. (2021). „What is new and true about fake news?“" Eds. R. Greinfeneder, M. E. Jaffé, E. J. Newman \& N. Schwartz. The Psychology of Fake News: Accepting, Sharing, and Correcting Misinformation. (pp. 1-8).

Habermas, J. (1991). The structural transformation of the public sphere: An inquiry into a category of bourgeois society. MIT press.

Herman, E. S., \& Chomsky, N. (2010). Manufacturing consent: The political economy of the mass media. Random House.

Jamieson, K., Cappella, J. (2008). Echo Chamber: Rush Limbaugh and the Conservative Media establishment. London: Oxford UP.

Kulić, M. (2019). „Definisanje lažnih vesti: stari koncept, novi pojmovi“‘. Ur. Z. Hrnjić Kuduzović, M. Kulić \& J. Jurišić. Vjerodostojnost medija: Doba lažnih informacija, zbornik radova devete regionalne naučne konferencije Vjerodostojnost medija, (pp. 5-19). Filozofski fakultet Univerziteta u Tuzli. 
Lévi-Strauss, C. (1968). Structural Anthropology: Translated from the French by Claire Jacobson and Brooke Grundfest Schoepf. Allen Lane, the Penguin Press.

Lule, J. (2001). Daily news, eternal stories: The mythological role of journalism. Guilford Press.

McIntyre, L. (2018). Post-truth. MIT Press.

Mead, G. H. (1934). Mind, self and society (Vol. 111). Chicago: University of Chicago Press.

Pariser, E. (2011). The filter bubble: What the Internet is hiding from you. Penguin UK.

Soules, M. (2015). Media, persuasion and propaganda. Edinburgh: Edinburgh University Press.

Stangor, C. (2016) The study of stereotyping, prejudice, and discrimination within social psychol-ogy: A quick history of theory and research. In: Nelson TD (ed.) Handbook of Prejudice, Stereotyping, and Discrimination. New York: Routledge, 3-27.

Steuter, E., \& Wills, D. (2009). At war with metaphor: media, propaganda, and racism in the war on terror. Lanham: Lexington books.

Sunstein, Cass R. (2001). Echo Chambers: Bush v. Gore, Impeachment, and Beyond. Princeton University Press.

Surčulija Milojević, J., Kulić, M. (2020). „Lažne vesti““ ili dezinformacije: (samo) regulatorni okvir i izazovi u praksi“. Srpska politička misao, br. 1/2020. god. 28.vol. 67, 117-203. Doi: https://doi.org/10.22182/spm.6712020.8

Tadić, D. (2005). Propaganda. Beograd: YU Spektrum.

Tanikawa, M. (2019). Stereotyping by historicizing: The journalistic writing technique of locating foreign societies in the past. Journalism, 1464884919870323.

Tandoc, Jr, C. E., Wei Lim, Z., Ling, R. (2018). „Defining ‘Fake News’“. Digital Journalism 6 (2):137-153, DOI: https://doi.org/10.1080/21670811.2017.1360143

Taylor, P. M. (2013). Munitions of the mind: A history of propaganda from the ancient world to the present era. Manchester University Press.

Vajdijanatan, S. (2018). Antidruštvene mreže. Beograd: Clio.

Vamanu, Iulian (2019). „Fake News and Propaganda: A Critical Discourse Research Perspective“. Open Information Science 2019; 3, pp. 197-208.

Van der Linden, S., Roozenbeek, J. (2021). „Psychological inoculation against fake news.“ Eds. R. Greinfeneder, M. E. Jaffé, E. J. Newman \& N. Schwartz. The Psychology of Fake News: Accepting, Sharing, and Correcting Misinformation. (pp. 147-169). London and New York: Routledge.

Vasović, M. D. (2004). Propagandne (ubeđivačke) tehnike u službi manipulacije javnim mnenjem. u: Vacić Z.[ur.]. Etika javne reči, Beograd: CLDS, 249-271. 


\section{PROPAGANDNE TEHNIKE U LAŽNIM VESTIMA OBJAVLJENIM U SRPSKIM MEJNSTRIM MEDIJIMA}

Sažetak: Posmatrajući propagandu kao esencijalni deo masmedijskih procesa, njene tehnike i svojstva, kako verbalna, tako i vizuelna, konstantno se menjaju i prilagođavaju novim trendovima. Kako je primetio Filip Tejlor (Philip Taylor), propaganda je: „,namerni pokušaj da se ljudi nateraju da se ponašaju i misle na određen način“", što se bazira na: ,, svesnim, metodičkim i planskim odlukama da se implementiraju određene tehnike persuazije stvorene da postignu specifične ciljeve kako bi korist imali organizatori takvih procesa" (Taylor, 2013: 6). Ukoliko prihvatimo definiciju lažnih vesti u Kembridžovom rečniku koji ih definiše kao: ,, lažne priče koje izgledaju kao vesti, šire se internetom ili preko drugih medija, obično se kreiraju sa ciljem da utiču na političke stavove ili u humorističke svrhe", onda relacija između dva pojma postaje posebno izražena, naročito u modernom dobu. U tom kontekstu, cilj ovog rada je da ispita koji propagandni aspekti su dominantni i na koji način su implementirani $u$ savremene lažne vesti koje su objavljene u srpskim mejnstrim medijima. Teorijski okvir je baziran na rezultatima modernih istraživanja u domenu propagandne komunikacije. Kroz kvalitativnu analizu autori su sproveli istraživanje fokusirajući se na detekciju $i$ analizu propagandnih tehnika korišćenim u potvrđenim lažnim vestima u srpskim mejnstrim medijima, a koje su otkrili $i$ dekonstruisali pouzdani $i$ verifikovani fekt čekeri (fact checkers) - Raskrinkavanje i Fake news tragač. Jedinica analize je tekst označen kao lažna vest. Od rezultata istraživanja se očekuje da pruže uvid u mehanizme kreiranja i širenja lažnih vesti kroz popularne mejnstrim medije koji su i dalje važan agens za kreiranje javnog mnjenja. U tom smislu ovi rezultati mogu biti iskorišćeni kao pokazatelj za bolju detekciju i borbu protiv lažnih vesti, ali i da podignu svest o važnosti medijske pismenosti kao jedne od najvažnijih kompetencija modernog doba.

Ključne reči: Lažne vesti, propaganda, provera činjenica, mejnstrim mediji 